三番茶の摘採が秋季の樹冠の群落構造に及ぼす影響

\author{
静岡県静岡空港建設事務所* \\ 中野敬之 \\ (平成20年 2 月 18 日受理)
}

\title{
Influences of Third Crop Plucking on Autumn Canopy Structure for Mature Tea (Camellia sinensis L.) Bush
}

\author{
Takayuki Nakano \\ Shizuoka Airport Construction Office
}

\begin{abstract}
Summary
Changes in autumn canopy structure of tea bushes between early-plucked (here after EP, yield was $421 \mathrm{~kg} / 10 \mathrm{a}$ on Aug. 1st in 2005), late-plucked (LP, $827 \mathrm{~kg} / 10 \mathrm{a}$ on Aug. 8th) and notplucked (NP) of the third crop was investigated by a stratiform clip method. All canopies of three bushes were cut with every $2 \mathrm{~cm}$ layer by a self-rail-tracking tea plucker on Oct. 19th in 2005. The result of vertical distribution of canopy biomass showed that the third crop plucking caused a decrease in leaf weight and bud number at the upper layers of the autumn canopy, but caused an increase in their lower layers. Although leaf weight of EP was same as that of LP, Leaf area index of EP was smaller however leaf specific weight was larger than LP. An analysis of relationship between autumn skiffing positions and bud number of the canopy surface was performed in order to estimate influences of the third crop plucking on new shoot number of the next first crop. The result was follows; the bud number of EP and LP was larger than that of $\mathrm{NP}$ at a lower autumn skiffing position (4 $\mathrm{cm}$ upper above the second plucking position), while bud number of NP was larger than EP and LP at a higher autumn skiffing position (6 $\mathrm{cm}$ upper).
\end{abstract}

Key words: Tea, first crop, third crop, canopy structure, stratiform analysis. キーワード : チャ, 一番茶, 三番茶, 樹冠, 層別刚り取り法

\section{1 緒言}

静岡農政事務所の調査によると，2006年の 静岡県の三番茶摘採面積は9468a，生葉生産
量は875トンで, それぞれ一番茶の5.0\%, $4.4 \%$ と僅かではあるものの，三番茶の生産が実際 に行われている1)。三番茶は低価格で採算が 難しく，炎天下での摘採作業を強いられるこ

\footnotetext{
于427-0019 静岡県島田市道悦 5 丁目 7 番 1 号
} 
とから, 地域, 経営体, 作業効率などの三番 茶の生産が行われる条件が限定されている。 その一方, 静岡県茶生産指導指針などの技術 指導書では, 三番茶の摘採は翌年一番茶の新 芽数を増加させる効果があると記載されてい ることから ${ }^{2,3,4)}$, 栽培現地では, 翌年一番茶 での新芽数の増加を目的にして, 三番茶の摘 採を実施している可能性もある。

筆者は, 前報5)において, 静岡県茶業試験 場の作況調査の1991年から2005年までの15年 間のデー夕を分析し, 三番茶摘採の有無が翌 年一, 二番茶の生育・収量に及ぼす影響を検 討した。その結果, 三番茶の摘採は, 翌年一 番茶の新芽数を増加させる効果は安定してお らず, むしろ, 高い確率で百芽重を減少させ, 一番茶の減収を招くことを指摘した ${ }^{5)}$ 。前報 は, 長期間の調査結果をまとめた信頼性の高 いものであるが，三番茶摘採の有無と翌年一 番茶を直接的に結びつけてその関係を解析し たのみであり，なぜそうなるのかを明らかに できなかった。また，三番茶の摘採の有無が その後の茶樹に対して具体的にどのような影 響を及ぼすかについては不明な点が多い。

ところで，私たちが普段から目にする茶樹 は樹冠の表面に限られ，その内部にある葉， 枝，芽がどのような分布をしてるのか，栽培 方法によってそれらの群落構造がどのように 変わるかについての知見は極めて少なく, 不 明な点が多い。特に摘採や整せん枝は，その 後の新梢の生育や枝条の発達に大きな影響を 及ぼすので, 樹冠内部の群落構造とその変動 特性を理解することは重要と考えられる。

そこで, 本報では, 三番茶を摘採した茶園 と摘採しなかった茶園について, 秋季に層別 刚り取り法で樹冠を解体して, 三番茶の摘採 が秋季における樹冠の群落構造に及ぼす影響 を詳細に検討したので報告する。

\section{2 材料および方法}

試験は，静岡県茶業試験場（現：静岡県農
林技術研究所茶業研究センター, 静岡県菊川 市倉沢1706の11）のA3ほ場で実施した。供 試園は，1984年 4 月に $180 \mathrm{~cm} \times 30 \mathrm{~cm}$ の単条植 えで定植した ‘やぶきた”園で, 1989年から軌 条走行式茶園管理装置 ${ }^{6)}$ で管理されている。 試験直前までの供試園の栽培経過について は, 一番茶は2005年 5 月 9 日に秋整枝位置より $1 \mathrm{~cm}$ 上の高さに刈刃を合わせて $663 \mathrm{~kg} / 10 \mathrm{a} の$ 収量で摘採し，5 月16日に一番茶の摘採位置 と同じ高さで整枝した。二番茶は 6 月 27 日に 一番茶摘採位置より $1 \mathrm{~cm}$ 上の高さで $520 \mathrm{~kg} / 10 \mathrm{a}$ で摘採し， 7 月 5 日に二番茶摘採位置と同じ 高さで整枝した。

試験構成は，三番茶早期摘採区，三番茶晚 期摘採区，三番茶不摘採区の 3 試験区で， 1 区 $1.8 \mathrm{~m} \times 5 \mathrm{~m}$ の 2 反復とした。早期摘採区は 2005 年 8 月 1 日, 晚期摘採区は 8 月 8 日に, 軌条走行式摘採機を用いて, 二番茶摘採位置 から $1 \mathrm{~cm}$ 上の高さに刈刃を合わせて三番茶 芽を摘採した。その後の整せん枝は行わず, 病害虫防除と施肥は慣行法で管理した。

2005年10月19日，新梢が繁茂した 3 試験区 について, 二番茶摘採位置の $12 \mathrm{~cm}$ 上から軌条 走行式摘採機（カワサキ機工株式会社製，走 行部型式RD21S, 刈刃部型式RV180）の刈刃を $2 \mathrm{~cm}$ 刻みに順次下げながら刈り取り，2 cm幅 の層別に樹冠の新梢を回収した。二番茶摘採 位置の $6 \mathrm{~cm}$ 下まで刈り取ると, 全ての区で樹 冠は消失し, 裾部以外に葉は見られなくなっ た。したがって，この操作によって茶樹の樹 冠のほとんどが層別に回収されたと判断した。

刈り取った各層毎に生重量を測定した後, 一部（約 $50 \mathrm{~g}$ ）を採集し，乾燥しないよう直 ちにビニール袋に入れて密封して，冷蔵庫に 保管した。その後, 葉と枝（硬化していない ものも含めた）に分離して各々の重量 (生重) を測定し，更に，枝数と枝に付いている頂芽 数，側芽数，不定芽数および蕾数を数えた。 なお，樹冠の下方に位置する古い枝では，葉 が葉柄基部から脱落した側芽と不定芽の違い 
が不明暸だったことから, 葉柄基部が付いて いない側芽は全て不定芽とした。葉面積は, 自動面積計（林電工株式会社製 AAM-8） を用いて測定した。

\section{3 結果}

早期摘採区，晚期摘採区における三番茶の 収量調査結果を表 1 に示した。早期摘採区は 8 月 1 日に $427 \mathrm{~kg} / 10 \mathrm{a}$, 晚期摘採区は 8 月 8 日に $812 \mathrm{~kg} / 10 \mathrm{a}$ の収量で摘採した（表 1 )。そ の後, 9 月の降水量が平年の $40 \%$ 程であった ためか, 秋季までの新梢の繁茂程度は, 達観 では平年に比べ若干劣る傾向であった。また， 晚期摘採区では成葉の硬化が遅れ，9月下旬 になっても成葉は黄緑色であった。

層別刚り取りによる新梢の重量および枝 · 葉別の重量割合の調查結果から 3 試験区にお

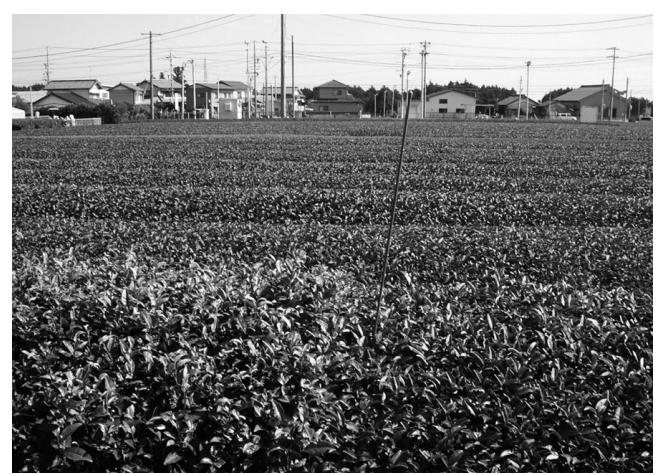

写真 1 層別刈り取り直前の状況（2005年10 月19日撮影)

左：三番茶不摘採区，右：三番茶早期摘採区
ける樹冠内の枝重, 葉重の垂直分布を算出し, 図 1 に示した。

枝重は，いずれの区も二番茶摘採位置から $4 \mathrm{~cm}$ 下 (以後 $-4 \sim 0 \mathrm{~cm}$ とする) までの $4 \mathrm{~cm}$ 幅で多く，三番茶早期摘採区では $-2 \sim 0 \mathrm{~cm}$ の層で特に多かった。三番茶を摘採した 2 区 における $+4 \mathrm{~cm}$ よりの樹冠の枝重は，早期 摘採区で $9 \mathrm{~kg} / 10 \mathrm{a}$ ，晚期摘採区で $3 \mathrm{~kg} / 10 \mathrm{a}$, 不摘採区の $90 \mathrm{~kg} / 10 \mathrm{a}$ に比べて顕著に少なかっ た（図 1 )。

葉重は, 三番茶摘採の有無に関係なく, 3 試 験区とも $+2 \sim+4 \mathrm{~cm}$ の層で最大值を示し, 晚期摘採区で最も多かった。その層が樹冠の 中心と考えられたので，その上下の樹冠を分 けて集計してみた。 $+4 \mathrm{~cm}$ よりの樹冠での 葉重を合計すると, 早期摘採区が $239 \mathrm{~kg} / 10 \mathrm{a}$, 晚期摘採区が $244 \mathrm{~kg} / 10 \mathrm{a}$, 不摘採区が $666 \mathrm{~kg} / 10 \mathrm{a}$ と不摘採区で多く，三番茶摘採の早晚では差 がなかった。一方， $+2 \mathrm{~cm}$ よ下の樹冠の葉 重を合計すると，早期摘採区が $635 \mathrm{~kg} / 10 \mathrm{a}$, 晚期摘採区が $604 \mathrm{~kg} / 10 \mathrm{a}$, 不摘採区が $472 \mathrm{~kg} / 10 \mathrm{a}$ となり，不摘採区で少なかった（図 1 )。

葉面積の測定で求めた葉面積指数（以下 LAI）を図 2 に示した。LAIは, 葉重と同様 な垂直分布を示し, $+2 \sim+4 \mathrm{~cm}$ 層で最大值 を示す分布になり, $+4 \mathrm{~cm}$ よ上の樹冠の LAIは不摘採区で多く, $+2 \mathrm{~cm}$ よ下の樹冠 のLAIは不摘採区で少なかった（図 2 )。

葉重と葉面積から, 単位面積当たりの葉重 （以下比葉重, $\mathrm{mg} / \mathrm{cm}^{2}$ ) を求め, その垂直

表 1 三番茶摘採区における収量と枠摘み調査結果

\begin{tabular}{lccccccc}
\hline \multirow{2}{*}{ 三番茶 } & \multirow{2}{*}{\begin{tabular}{c} 
摘採日 \\
\cline { 4 - 8 }
\end{tabular}} & 月日 & 収量 & \multicolumn{5}{c}{ 枠 $(20 \mathrm{~cm} \times 20 \mathrm{~cm})$} & 摘み調查結果 \\
\cline { 4 - 8 } & $\mathrm{kg} / 10 \mathrm{a}$ & $\begin{array}{c}\text { 摘芽数 } \\
\text { 本 }\end{array}$ & $\begin{array}{c}\text { 百芽重 } \\
\mathrm{g}\end{array}$ & $\begin{array}{c}\text { 摘芽長 } \\
\mathrm{cm}\end{array}$ & $\begin{array}{c}\text { 新葉数 } \\
\text { 枚 }\end{array}$ & $\begin{array}{c}\text { 出開度 } \\
\%\end{array}$ \\
\hline 早期摘採区 & 8 月 1 日 & 427 & 62 & 29.9 & 2.1 & 2.8 & 69 \\
晚期摘採区 & 8 月 8 日 & 812 & 76 & 54.4 & $2.7^{2)}$ & 3.0 & 100 \\
\hline 分散分析による有意性 & $* * 1)$ & N.S. & N.S. & N.S. & N.S. & N.S. \\
\hline
\end{tabular}

1），**は，それぞれ $5 \% ， 1 \%$ 水準で有意。

2 ）約 20 芽調査した調査個体間の変動係数は約 $70 \%$ あった。 


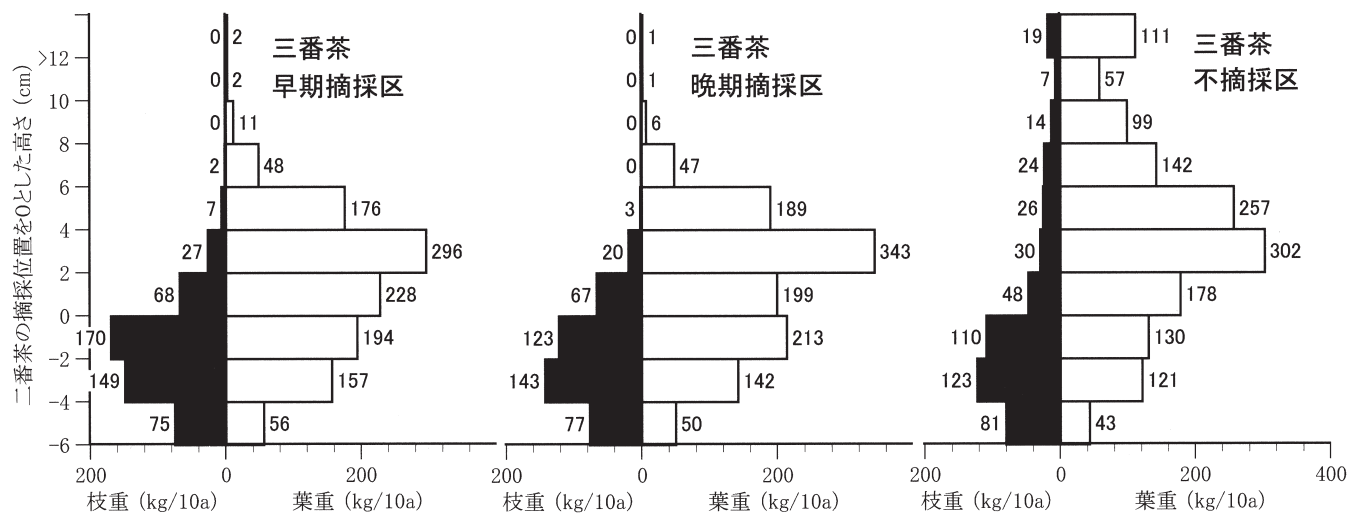

図 1 三番茶摘採の有無と摘採時期の早晚が秋季における樹冠の枝重, 葉重に及ぼす影響

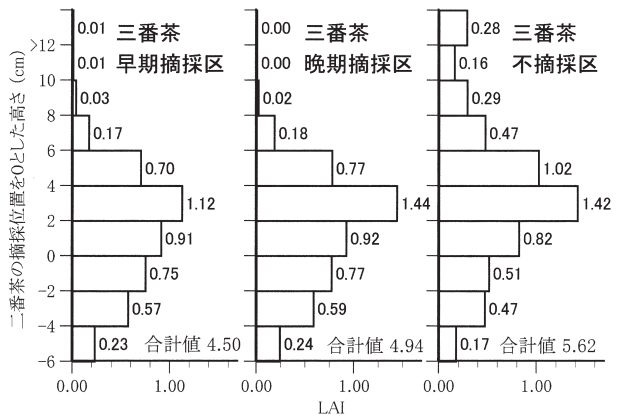

図 2 三番茶摘採の有無と摘採時期の早晚が秋 季における樹冠の葉面積指数（LAI）に 及ぼす影響

分布を図 3 に示した。比葉重は， $+4 \mathrm{~cm}$ より も上の樹冠では不摘採区が最も大きかった が， $+4 \mathrm{~cm}$ よも下の樹冠では早期摘採区が 最も大きかった。三番茶の摘採時期の違いに ついては，最上層である $>+12 \mathrm{~cm}$ を除く全て の層で，晚期摘採区の比葉重は早期摘採区よ りも小さかった（図 3 )。

層別の枝数，芽数の分布を図 4 に，芽数の うち，頂芽，側芽，不定芽に分けた実数を表 2 に示した。

枝数は， 3 試験区とも $-2 \sim 0 \mathrm{~cm}$ で最多值 を示したが，早期摘採区で特に多かった。 3 試験区とも，-2〜0 cmより上層ほど枝数は 少なかったが，不摘採区の枝数は $0 〜+4 \mathrm{~cm}$ では三番茶を摘採した 2 区よりも少なく，そ

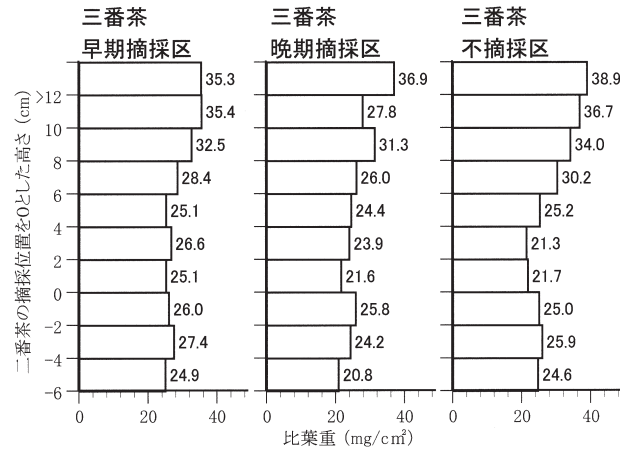

図 3 三番茶摘採の有無と摘採時期の早晚が秋 季における樹冠の比葉重に及ぼす影響

れより上では多かった。早期摘採区では +8 $\mathrm{cm}$ よ上，晚期摘採区では $+6 \mathrm{~cm}$ よ上は， 枝数が 10 本 $/ \mathrm{m}^{2}$ 以下であった（図 4 ）。

総芽数は，早期摘採区と不摘採区では -2 $\sim 0 \mathrm{~cm}$ で，晚期摘採区では $0 \sim+2 \mathrm{~cm}$ で最大 值を示した。 $-4 \sim+4 \mathrm{~cm}$ の総芽数は，不摘 採区よりも三番茶を摘採した 2 区が多かった が， $+4 \mathrm{~cm}$ よ上では不摘採区の方が多かっ た。三番茶の摘採時期の違いについては，全 ての層において，早期摘採区は晚期摘採区よ りも多かった（図 4 ）。

頂芽数は, 三番茶を摘採した 2 区では -2 〜 $+4 \mathrm{~cm}$ で，不摘採区では $0 \sim+4 \mathrm{~cm}$ で多か った。 3 試験区とも 0 〜 $2 \mathrm{~cm}$ で最多值を示 したが，試験区間では不摘採区で少なかった 


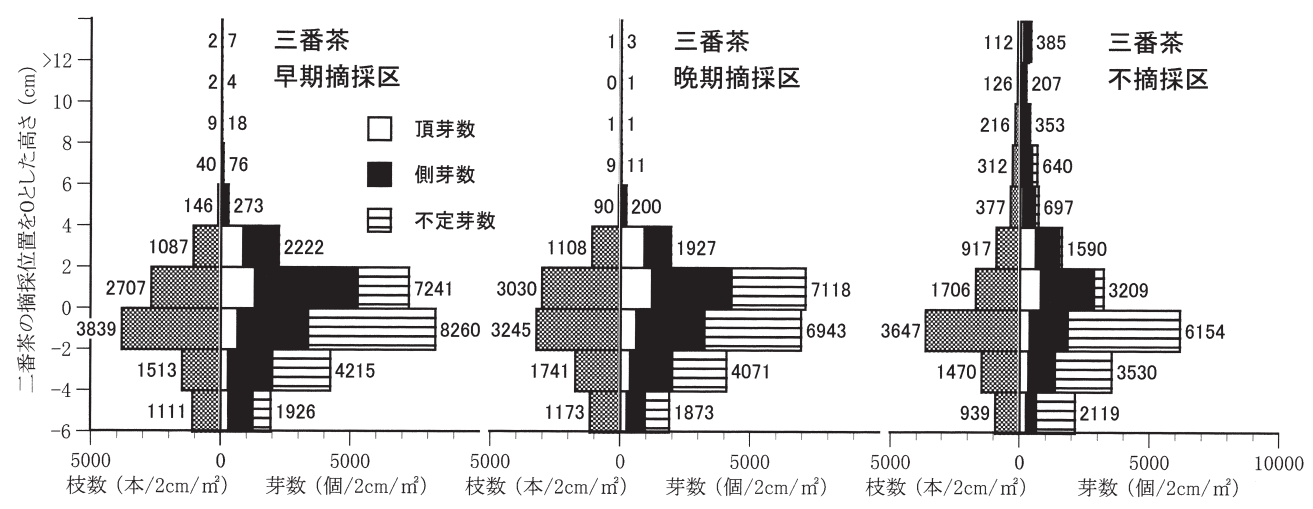

図 4 三番茶摘採の有無と摘採時期の早晚が秋季における樹冠内の枝数, 芽数に及ぼす影響 注）図中に記した值は，層毎の枝数と総芽数（頂芽，側芽，不定芽の合計值）

表 2 三番茶摘採の有無と時期の早晚が秋季の樹冠における頂芽, 側芽, 不定芽数に及ぼす影響

\begin{tabular}{|c|c|c|c|c|c|c|c|c|c|c|c|}
\hline \multirow{2}{*}{\multicolumn{3}{|c|}{$\begin{array}{l}\text { 二番茶摘採位置 } \\
\text { を基準とした高 } \\
\text { さ } \mathrm{cm} \\
\end{array}$}} & \multicolumn{3}{|c|}{ 三番茶早期摘採区 } & \multicolumn{3}{|c|}{ 三番茶晚期摘採区 } & \multicolumn{3}{|c|}{ 三番茶不摘採区 } \\
\hline & & & 頂芽 & 側芽 & 不定芽 & 頂芽 & 側芽 & 不定芽 & 頂芽 & 側芽 & 不定芽 \\
\hline$y^{2}$ & + & & 2 & 5 & 0 & 1 & 2 & 0 & 112 & 271 & 2 \\
\hline+10 & $\sim$ & +12 & 1 & 3 & 0 & 0 & 1 & 1 & 46 & 143 & 18 \\
\hline+8 & $\sim$ & +10 & 5 & 11 & 2 & 1 & 1 & 0 & 68 & 238 & 47 \\
\hline+6 & $\sim$ & +8 & 21 & 49 & 7 & 6 & 5 & 0 & 68 & 376 & 197 \\
\hline+4 & $\sim$ & +6 & 84 & 169 & 20 & 70 & 127 & 3 & 105 & 449 & 142 \\
\hline+2 & $\sim$ & +4 & 842 & 1339 & 42 & 901 & 989 & 38 & 589 & 894 & 106 \\
\hline 0 & $\sim$ & +2 & 1304 & 3964 & 1973 & 1202 & 3061 & 2854 & 793 & 2044 & 371 \\
\hline-2 & $\sim$ & 0 & 628 & 2734 & 4895 & 599 & 2627 & 3716 & 362 & 1479 & 4313 \\
\hline-4 & $\sim$ & -2 & 273 & 1714 & 2227 & 359 & 1633 & 2079 & 324 & 1030 & 2176 \\
\hline-6 & $\sim$ & -4 & 299 & 942 & 685 & 238 & 710 & 926 & 241 & 390 & 1488 \\
\hline
\end{tabular}

1 ）表中の数值は，幅 $2 \mathrm{~cm}$ 層の芽数（個 $/ \mathrm{m}^{2} ）$ を示す。

(表 2 )。

側芽数は, 3 試験区とも $0 \sim+2 \mathrm{~cm}$ で最多 值を示し, $-2 \sim 0 \mathrm{~cm}>-4 \sim-2 \mathrm{~cm}>+2$ 〜+4 cmの順に多かった。これらの各層の側 芽数はいずれも，早期摘採区 $>$ 晚期摘採区 $>$ 不摘採区の順に多かった。しかし， $+4 \mathrm{~cm}$ り上の樹冠では，三番茶を摘採した二つの試 験区の側芽数は，不摘採区に比べて著しく少 なかった（表 2$) 。$

不定芽数は， 3 試験区とも $-2 \sim 0 \mathrm{~cm}$ で最 多值を示し， -4 〜 $2 \mathrm{~cm}$ も多かった。 0 〜 $+2 \mathrm{~cm}$ では, 晚期摘採区が多く, 不摘採区は 顕著に少なかった（表 2$)$ 。

層別の蕾数を図 5 に示した。樹冠全層にお

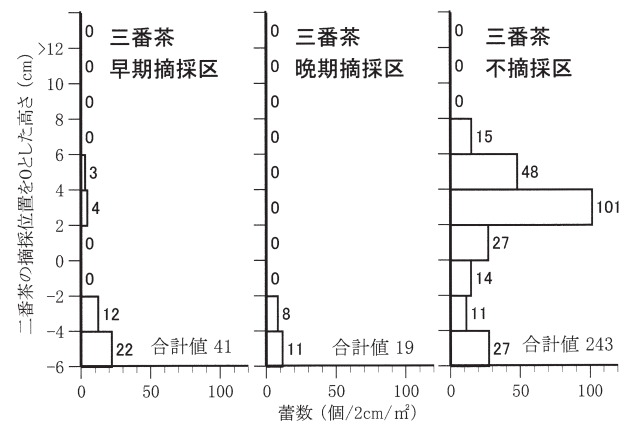

図 5 三番茶摘採の有無と摘採時期の早晚が秋 季における樹冠内の蕾数に及ぼす影響

ける蕾数は，早期摘採区が 41 個 $/ \mathrm{m}^{2}$, 晚期摘 採区が 19 個 $/ \mathrm{m}^{2}$ ，不摘採区が 243 個/ $\mathrm{m}^{2}$ で不摘 採区が顕著に多く,晚期摘採区が少なかった。 
三番茶を摘採した 2 区は, $-2 \mathrm{~cm}$ よ上の樹 冠に蕾がほとんどなく, 特に晚期摘採区では 全くみられなかった（図 5 )。

\section{4 考察}

筆者は，秋季におけるチャ樹冠の群落構造 に関して, 三番茶不摘採園における二番茶摘 採時期の影響について, 軌条走行式摘採機を 用いた層別刈り取り法で検討した ${ }^{7)}$ 。その結 果，二番茶の摘採時期が異なるだけで，秋季 の樹冠の群落構造は大きく異なり, 二番茶を 早期に低収量で摘採すると, 新梢は上層に伸 びて徒長化し, 秋整枝位置付近の葉重, 葉面 積, 芽数が極端に少ない群落構造を呈した。 本研究では, 三番茶摘採の有無という, より 大きな影響を及ぼす要因についての調査であ るが, 過去に類似研究はなく, 本報が初めて の試みである。

本研究で明らかになった三番茶摘採の有無 が秋季の樹冠に及ぼす影響は, 図 1 ～ 5 と表 2 に示したとおりで，三番茶を摘採すると， 葉重は樹冠上層で減少するが樹冠下層で増加 すること, また, 樹冠全域の芽数が増加する などの幾つかの形質に変化が認められた。し かし, 枝葉や茶芽の樹冠内分布について, 単に 試験区間の違いを比較するだけでは，三番茶
の摘採がその後の樹冠形成に及ぼした影響に ついて理解を深めることはできない。そのた めには，各試験区の樹冠を構成する枝葉が形 成された茶期に着目して解析する必要がある。

本研究では, 試験前年の秋整枝は, 二番茶 摘採位置より $5 \mathrm{~cm}$ 上, 試験当年の一〜三番茶 の摘採は, 前回の摘採・整枝位置より $1 \mathrm{~cm}$ 上 で行っている。一番茶の新芽は，樹冠のほぼ 全域から伸長するが, 収穫対象になるのは秋 整枝後の樹冠面から $2 \mathrm{~cm}$ 下までの表層から 生育したものがほとんどを占めると指摘され ている ${ }^{8)}$ 。一方，二番茶以降では，枝条の頂 部に位置する新芽のみが生育することが知ら れている ${ }^{9)}$ 。これらの試験経過や知見に従っ て, 一番茶芽は樹冠の全域から, 二〜四番茶 芽は前回摘採・整枝した樹冠面から $2 \mathrm{~cm}$ 下ま での範囲から新芽が伸長するものと仮定した。 また，表 1 に示した三番茶晚期摘採区での摘 芽長は $2.7 \mathrm{~cm}$ であったが，調査した個体間の 変動係数が70\%だったことから, 三番茶芽の 新芽はほとんどが $0.8 〜 4.6 \mathrm{~cm}$ 範囲で生育を 停止したものと仮定した。図 1 に示した三番 茶早期摘採区と不摘採区での樹冠の枝葉の重 量分布に各々の組織が形成された茶期を書き 达み，その結果を図 6 に示した。

三番茶早期摘採区に扔ける $-2 \sim 0 \mathrm{~cm}$ の枝
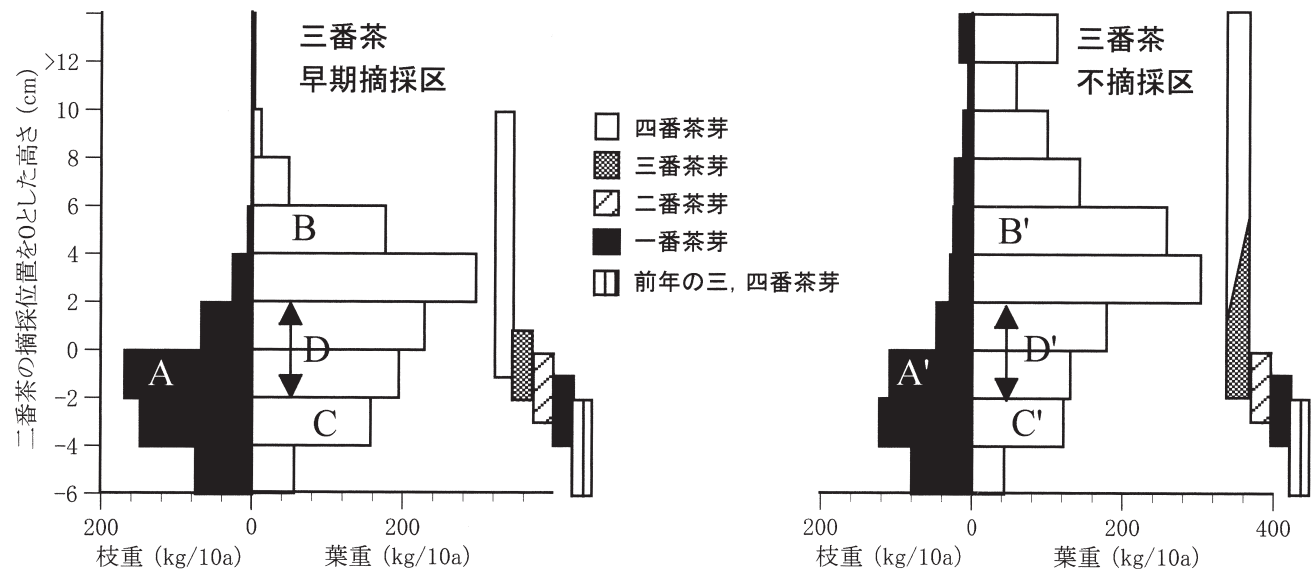

図 6 秋季における樹冠内の枝重と葉重の分布と枝葉が形成された茶期 


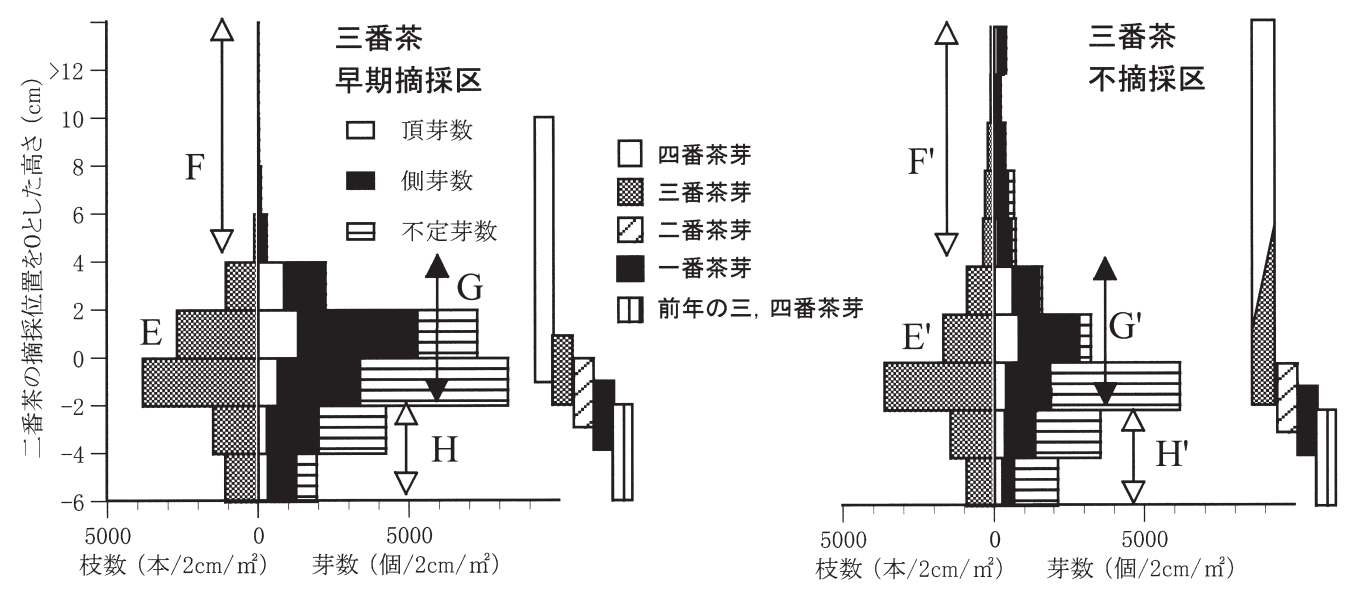

図 7 秋季における樹冠内の枝数と芽数の分布と枝葉が形成された茶期

重（A）は，不摘採区（ $\left.\mathrm{A}^{\prime}\right)$ よりも多かった。 この点については, 早期摘採区のAでは一〜 四番茶芽の茎に由来する枝が含まれているこ とに対し，不摘採区の $\mathrm{A}^{\prime}$ では一〜三番茶芽 に由来するので，四番茶芽に由来する分だけ 枝重が少なかったことが原因と考えられる。 一方，三番茶早期摘採区に拈ける $+4 \sim+6$ $\mathrm{cm}$ の葉重（B）は四番茶芽の上位葉のみに 由来するが，不摘採区（ $\left.\mathrm{B}^{\prime}\right)$ では三番茶芽の 上位葉と四番茶芽の下位葉に由来するものが 含まれているので， $\mathrm{B}^{\prime}$ の葉重が多くなったと 考えられる（図6)。

樹冠下位の-6〜-2 cmの葉重については, 三番茶不摘採区（ $\mathrm{C}^{\prime} ）$ は早期摘採区 $(\mathrm{C})$ よ りも明らかに少なく, 早期摘採区が $213 \mathrm{~kg} / 10 \mathrm{a}$, 晚期摘採区が $192 \mathrm{~kg} / 10 \mathrm{a}$, 不摘採区が $164 \mathrm{~kg} / 10 \mathrm{a}$ であった。これらの部位には三番茶以後の新 芽は含まれていないので, 三番茶の摘採まで は試験区間に差が無かった筈である。前述し たように，二番茶以後は樹冠内部から新芽が 生育しない特性があるので9)，Cの葉重が三 番茶摘採後に増加したのではなく, $\mathrm{C}^{\prime}$ の葉重 が減少したと考えられる。図 2 から， $-2 \mathrm{~cm}$ より上の樹冠上位におけるLAIを集計する と, 早期摘採区が 3.7 , 晚期摘採区が 4.1 , 不 摘採区が5.0であった。樹冠上位のLAIが大き
いと樹冠下位は透過光が少ないと考えられ， 光合成の低下がC'での落葉の増加を招いた と考えられる(図6)。

二番茶摘採位置付近の $-2 \sim+2 \mathrm{~cm}$ の葉重 は, 三番茶早期摘採区（D）ょり不摘採区 ( $\left.\mathrm{D}^{\prime}\right)$ が少なかった。この部位については， $\mathrm{D}$ に四番茶芽の下葉が多く含まれていること と, 透過光が少ない $\mathrm{D}^{\prime}$ での葉重の減少が影響 していると考えられる。ただ，どちらの要因 が大きく影響しているかは，この結果からは 判断できない（図 6 )。

図 2 の三番茶早期摘採区と不摘採区につい ての樹冠の枝数と芽数の分布に各々の組織が 形成された茶期を書き込み，図 7 に示した。

頂芽は新梢の頂部にあるので，秋季の樹冠 における頂芽の多少と分布は，三番茶摘採園 では三番茶摘採位置から伸長した四番茶芽の 本数と長さによって決定される。一方, 三番 茶不摘採園では少し複雑で, 二番茶摘採位置 から伸長した三番茶芽の本数と長さが基準に なるが，その頂部から四番茶芽として更に上 方に伸長した新芽と，伸長せずに秋まで生育 が停止した三番茶芽が混在していると考えら れ, 頂芽の分布はそれらの性格の異なる新芽 の生育状況によって変動する。

側芽は, 葉柄基部にあるので, 上述した三， 
四番茶芽の長さに加えて, 新芽の葉数や節間 長が側芽の分布に影響すると考えられる。不 定芽は, 枝の不規則な部位に発生しているが, どのような状況で密度が変わるか不明な点が 多いものの，基本的には枝数に比例すると考 えられる。

以上に示した点を考慮して図 7 における三 番茶早期摘採区と不摘採区での枝数を比較す

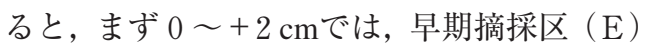

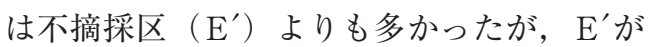
三番茶芽に由来するもののみであることに対 して， $\mathrm{E} は$ 摘採で切断されて残った三番茶芽 の下部と四番茶芽の合計に由来するため多く なったと考えられる。一方， $+4 \mathrm{~cm}$ よ上方 では，早期摘採区（F）は不摘採区（ $\mathrm{F}^{\prime} ）$ よりも少なかったが, 四番茶芽の伸長が $\mathrm{F} ま$ で届かなかったことに対して， $\mathrm{F}^{\prime}$ は三番茶 芽の頂部から更に上方に向けて四番茶芽が伸 長したものが含まれるので $\mathrm{F}^{\prime}$ の枝数が多く なったと考えられる（図 7 )。

芽数の違いについては， $+4 \mathrm{~cm}$ よも上層 では，早期摘採区（ $\mathrm{G} ）$ は不摘採区（ $\left.\mathrm{G}^{\prime}{ }^{\prime}\right)$ よりも少なかったが, 上方に伸長した四番茶 芽の枝数の差が影響していると考えられる。 一方, $-2 \sim+4 \mathrm{~cm}$ 芽数については, 早期
摘採区 $(\mathrm{H})$ は不摘採区 $\left(\mathrm{H}^{\prime}\right)$ よりもかなり

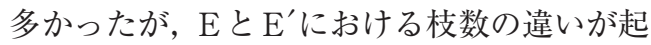
因していると考えられる。 $-6 \sim-2 \mathrm{~cm}$ 芽 数については, 早期摘採区 $(\mathrm{I})$ は, 不摘採区 ( I') よりも側芽数が多く不定芽数が少なか ったが，上述したように，図 6 のC'で落葉が 多かったとする推定が正しければ，側芽が不 定芽として計数された可能性が高い（図 7 )。

以上に示した解析より, 三番茶の摘採は, 二番茶摘採位置付近での枝重, 枝数, 芽数を 増加させること, 二番茶摘採位置の $+4 \mathrm{~cm}$ よ り上の樹冠上位の葉重, 枝数, 芽数を減少さ せること, 更に, 二番茶摘採位置の $+2 \mathrm{~cm}$ よ り下の樹冠下位での葉重を減少させないこと が明らかになった。

ところで, 本研究の目的は, 三番茶摘採の 有無や摘採時期の早晚の違いが秋季までの樹 冠形成にどのような差違をもたらして，その 結果として翌年一番茶にどのような影響を及 ぼすかについての解明である。そこで，一番 茶芽が伸長する秋整枝面付近での群落構造に 着目するため, 各試験区で秋整枝した後にお ける樹冠内の枝重, 葉重, LAI, 比葉重, 蕾 数と秋整枝面表層 $2 \mathrm{~cm}$ 幅での芽数を計算し, 表 3 に示した。

表 3 三番茶摘採の有無と摘採時期の早晚が秋整枝後の樹冠に及ぼす影響1)

\begin{tabular}{|c|c|c|c|c|c|c|c|c|c|}
\hline \multirow{2}{*}{$\begin{array}{l}* \text { *試験区 } \\
\text { 秋整枝の高さ2) }\end{array}$} & \multicolumn{5}{|c|}{ 秋整枝面下の群落構造 ${ }^{3)}$} & \multicolumn{4}{|c|}{ 秋整枝面表層 $2 \mathrm{~cm}$ 幅の芽数 } \\
\hline & $\begin{array}{c}\text { 枝重 } \\
\mathrm{kg} / 10 \mathrm{a}\end{array}$ & $\begin{array}{l}\text { 葉重 } \\
\mathrm{kg} / 10 \mathrm{a}\end{array}$ & LAI & $\begin{array}{l}\text { 比葉重 } \\
\mathrm{mg} / \mathrm{cm}^{2}\end{array}$ & $\begin{array}{l}\text { 蕾数 } \\
\text { 個 } / \mathrm{m}^{2}\end{array}$ & $\begin{array}{l}\text { 頂芽 } \\
\text { 個 } / \mathrm{m}^{2}\end{array}$ & $\begin{array}{l}\text { 側芽 } \\
\text { 個 } / \mathrm{m}^{2}\end{array}$ & $\begin{array}{l}\text { 不定芽 } \\
\text { 個/m² }\end{array}$ & $\begin{array}{l}\text { 合計 } \\
\text { 個 } / \mathrm{m}^{2}\end{array}$ \\
\hline \multicolumn{10}{|l|}{ *三番茶早期摘採区 } \\
\hline $6 \mathrm{~cm}$ 上 & 497 & 1106 & 4.28 & 25.8 & 41 & 84 & 169 & 20 & 273 \\
\hline $4 \mathrm{~cm}$ 上 & 490 & 930 & 3.59 & 25.9 & 38 & 842 & 1339 & 42 & 2223 \\
\hline \multicolumn{10}{|l|}{ *三番茶晚期摘採区 } \\
\hline $6 \mathrm{~cm}$ 上 & 432 & 1136 & 4.73 & 24.0 & 19 & 70 & 127 & 3 & 200 \\
\hline $4 \mathrm{~cm}$ 上 & 430 & 947 & 3.96 & 23.9 & 19 & 901 & 989 & 38 & 1927 \\
\hline \multicolumn{10}{|l|}{ *三番茶不摘採区 } \\
\hline $6 \mathrm{~cm}$ 上 & 417 & 1032 & 4.42 & 23.3 & 228 & 105 & 449 & 142 & 697 \\
\hline $4 \mathrm{~cm}$ 上 & 391 & 775 & 3.40 & 22.8 & 180 & 589 & 894 & 106 & 1590 \\
\hline
\end{tabular}

1 ）表中の值は, 図 1 〜 5 に示したデータから算出した。

2 ）二番茶摘採位置からの高さを示す。

3 ）二番茶摘採位置の $6 \mathrm{~cm}$ 下から秋整枝面までの樹冠。 
前報でも記述したが, 三番茶の摘採が翌年 一番茶に及ぼす影響は, 秋整枝位置によって 異なる結果が予想される ${ }^{5)}$ 。新茶業全書によ ると, 秋整枝の位置について, 三番茶摘採園 では葉層を $8 \mathrm{~cm}$ 以上で四番茶葉を 3 枚程度残 すよう, 不摘採園では葉層を $8 \mathrm{~cm}$ 以上確保で きれば二番茶摘採位置から $4 \sim 5 \mathrm{~cm}$ 上で三番 茶葉を 2 枚程度残すように行うと記載されて いる ${ }^{10)}$ 。一方，筆者は軌条走行式摘採機を用 いて $5 \mathrm{~mm}$ 単位で秋整枝位置を変えて行った 試験結果より, 三番茶不摘採園での秋整枝は 二番茶の摘採面から 5 ～ $6 \mathrm{~cm}$ 上が適值である と報告した ${ }^{11)}$ 。これらを参考に，また，図 1 , 2 から秋整枝後の葉層の厚さが $8 \mathrm{~cm}$ 以上ある ことを確認して, 二番茶摘採位置から $4 \mathrm{~cm}$ 上 と $6 \mathrm{~cm}$ 上の位置で秋整枝した場合での樹冠の 群落構造を表 3 に示した。

その結果， 3 試験区とも秋整枝位置の高低 によって秋整枝面下の葉重, LAI, 秋整枝面 表層 $2 \mathrm{~cm}$ 幅の頂芽数と側芽数が大きく変化し, 秋整枝位置が低いと葉重, LAIは減少するが, 表層の芽数が大幅に増加した。ただ，このよ うな特性は三番茶の摘採の有無によって傾向 が異なり，例えば，秋整枝位置を $2 \mathrm{~cm}$ 下げる ことによる葉重の変化を計算してみると, 三 番茶早期摘採区で $176 \mathrm{~kg} / 10 \mathrm{a}$ 減, 晚期摘採区 で189kg/10a減, 不摘採区で $257 \mathrm{~kg} / 10 \mathrm{a}$ 減とな り，三番茶不摘採区で減少量が多くなった。 一方, 秋整枝位置を $2 \mathrm{~cm}$ 下げることによる芽 数の変化は, 早期摘採区で1950個/ $\mathrm{m}^{2}$ 増, 晚期 摘採区で 1727 個 $/ \mathrm{m}^{2}$ 増, 不摘採区で 893 個 $/ \mathrm{m}^{2}$ 増となり，三番茶を摘採した二つの試験区の 増加量が多かった。このような特性により, 秋整枝後の樹冠面の芽数は秋整枝位置によっ て試験区間の多少が異なり, 秋整枝位置が 6 $\mathrm{cm}$ 上では三番茶不摘採区で多かったが， $4 \mathrm{~cm}$ 上では三番茶を摘採した二つの試験区で多か った（表 3 )。

ところで, 一番茶期は芽の脇部からも新芽 が生育するが，秋季の時点ではその腋芽は形
成されていない。したがって，一番茶の新芽 数は秋季の樹冠面での芽数よりも増加する特 性がある。筆者は, 三番茶不摘採園で秋整枝 直後の樹冠面の芽数と翌年一番茶の新芽数と の関係を調査した ${ }^{12)}$ 。その結果を具体的に示 すと, 二番茶の摘採位置から $4 \mathrm{~cm}$ 上での秋整

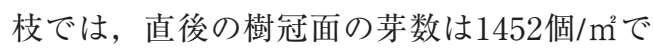
あったが，翌年一番茶の新芽数は 1940 本 $/ \mathrm{m}^{2}$ と34\%増加した。一方, 二番茶摘採位置から $6 \mathrm{~cm}$ 上での秋整枝では, 樹冠面の芽数は 1131 個 $/ \mathrm{m}^{2}$ で, 翌年一番茶の新芽数は 1746 本 $/ \mathrm{m}^{2}$ と $54 \%$ も増加し, 秋季での樹冠面の芽数の差よ りも翌年一番茶での新芽数の差が縮まった ${ }^{12)}$ 。 三番茶摘採園では, 頂芽, 側芽および不定芽 の構成比率が不摘採園と異なるので，翌年一 番茶の新芽数が秋季の芽数よりもどの程度増 加するかは明らかでない。したがって，三番 茶摘採の有無が翌年一番茶の新芽数に及ぼす 影響を表 3 の結果のみから判断することは危 険であり, 今後更に検討していく必要がある。

筆者は前報において, 三番茶を摘採すると 翌年一, 二番茶の百芽重は非常に高い確率で 減少して, 減収を招きやすくなることを指摘 した ${ }^{5)}$ 。百芽重の減少は，新芽数が減少した 場合でも常に観測されたので，新芽数が多い と百芽重が減少するという従来からの一般論 に当てはまらなかった。表 3 に示した秋整枝 面下の樹冠において, 三番茶を摘採した二つ の試験区では，不摘採区よりも樹冠内の枝重 と葉重が多く, 比葉重が大きく, 蕾数が少な かった。また，樹冠内の芽数では，頂芽が占 める比率が高いことが三番茶を摘採した二つ の試験区の特徵であったが，これらの特性が 翌年一番茶の百芽重を減少させるメカニズム とどのような係わりがあるのかは明らかでは ない。

三番茶の摘採が翌年一番茶の百芽重を減少 させうるその他要因としては，図 6 に示した ような樹冠内での葉重の分布が, 受光体勢と 光合成，呼吸量，蒸散による水分収支に及ぼ 
す影響等が挙げられる。特に, 三番茶摘採区 での樹冠下部に形成される多くの葉は上層の 遮蔽によって光の到達量が少ないと考えら れ，これが茶樹にどのような影響を及ぼして いるのかについては興味深い。今後は，これ らの要因についての検討が必要であろう。

三番茶の摘採時期と翌年一番茶の関係につ いて, 創立 80 周年記念 静岡県茶業試験場成 績収録 ${ }^{13)}$ では, 三番茶を 5 日間隔間で 4 回に 分けて摘採して翌年の一番茶収量との関係を 調查した結果，供試した 5 品種とも三番茶の 摘採日が遅いほど翌年一番茶収量が減小した データが掲載されている。このため, 本研究 では, 早期摘採区と晚期摘採区に分けて, 三 番茶の摘採時期の影響についても検討した。 三番茶の晚期摘採が，その後の茶樹に及ぼす 影響としては, 三番茶の摘採から秋整枝まで の新梢の生育期間の短縮化と多収量の摘採に よる樹体内での栄養成分等の減少の 2 点が考 えられる。

三番茶の摘採時期の違いが秋整枝後の樹冠 の群落構造に及ぼす影響については, 早期摘 採区の方が樹冠内の枝重が大きかった。葉重 は区間に差がなかったが，LAIは晚期摘採区 の方が大きく，比葉重は早期摘採区の方が大 きかった。樹冠表層の芽数は早期摘採区の方 が多く, 特に側芽数での差が大きかった（表 3 )。

比葉重は葉の厚みを表す指標として用いら れるが, 一般に比葉重が大きい葉は, 窒素含 有量が高いことが知られている。チャに関す る研究で比葉重が検討された事例は少ないも のの, 比葉重は品種によって大きな差違があ ること, 同じ茶樹でも上位葉ほど大きく下位 葉ほど小さいこと ${ }^{14)}$, 強度に遮光すると小さ くなること ${ }^{15)}$ が明らかにされ, 比葉重の大小 が日照条件に大きく影響すると考えられる。 本結果では三番茶不摘採区の樹冠下層（秋整 枝面下の樹冠）での比葉重が小さかったが, 樹冠上層に繁茂した新梢によって日照が遮ら
れたことが原因と考えられる。一方，晚期摘 採区の比葉重が樹冠のほぼ全層で早期摘採区 よりも小さかった原因については，両試験区 間での新梢の繁茂状況にほとんど差がなかっ たことから，日照以外の影響によるものと考 えられる。日照に起因しない比葉重の差違の 原因と，それが翌年一番茶にどのような影響 を及ぼすか解明していくことも今後の課題で ある。

\section{5 摘要}

三番茶を 8 月 1 日に $421 \mathrm{~kg} / 10 \mathrm{a}$ で摘採した 早期摘採区， 8 月 8 日に $812 \mathrm{~kg} / 10 \mathrm{a} て ゙$ 摘採し た晚期摘採区および不摘採区において，10月 19日に樹冠を層別に刈り取って，秋季での樹 冠の群落構造を調査した。その結果, 三番茶 摘採区は不摘採区に比較して, 二番茶摘採位 置の $+4 \mathrm{~cm}$ よ上の樹冠上位の葉重, 枝数, 芽数が少なかったが，二番茶摘採位置の +2 cmより下の樹冠下位での葉重が多かった。こ の調査結果より秋整枝後の樹冠の構成につい て推計した結果, 樹冠面の芽数は, 秋整枝位 置の僅かな上下で大きく変動する特性があ り, 高めの秋整枝では三番茶不摘採区の方が 多かったが，低めの秋整枝では三番茶摘採区 の方が多かった。秋整枝後の樹冠について, 三番茶の摘採の有無で比較すると, 枝重と比 葉重は摘採区が大きく，蕾数は不摘採区が多 かった。秋整枝後の樹冠について, 三番茶の 摘採時期の違いを比較すると, 早期摘採区の 方が樹冠の枝重が大きかった。葉重は三番茶 摘採の早晚による差がなかったが, LAIは晚 期摘採区の方が大きく，比葉重は早期摘採区 の方が大きかった。秋整枝後の樹冠表層の芽 数は早期摘採区の方が多く, 特に側芽数が多 かった。

\section{6 引用文 献}

1 ) 静岡県農業水産部お茶室 (2007)：静岡県 茶業の現状 - 静岡県茶業振興基本計画の 
評価・分析 - 平成19年 3 月. 静岡, pp. 96 .

2 ) 静岡県農林水産部 (2000): 茶生産指導指 針・平成 12 年 6 月. 静岡, pp. 51 .

3 ) 大石貞男 (1985)：茶栽培全科. 農山漁村 文化協会，東京，pp. 144-146.

4 ) 木村政美 (2006)：茶園管理12力月 生育 の見方と作業のポイント。社団法人農産 漁村文化協会, 東京, pp. 82-85.

5 ) 中野敬之 (2007)：三番茶摘採の有無が翌 年の一, 二番茶に及ぼす影響。茶研報, No.103, 61-68.

6 ）中野敬之・後藤昇一・倉貫幸一・鈴木康 孝・谷 博司 (1998)：静岡県における軌 条走行式茶園管理装置の開発経過および 普及状況. 日作東海支部報 126，9-14.

7 ) 中野敬之 (2000)：二番茶摘採の早晚が秋 季における樹冠の群落構造に及ぼす影 響。茶研報 No.89, 37-44.

8 ）中山 仰 (1967)：はさみ摘み茶園におけ る茶芽の垂直分布. 茶技研No.35, 40-44.

9 ）土井芳憲 - 中山 仰 (1978)：一番茶の摘
芽位置の違いによる二番茶の再生. 茶技 研 55, 7-11.

10）大場正明 (1988)：摘採整枝. 静岡県茶業 会議所編, 新茶業全書 8 版, 静岡県茶業 会議所, 静岡, pp. 168-182.

11）中野敬之(1998）：三番茶不摘採園におけ る秋整枝位置の高低が翌年一番茶に及ほ す影響。茶研報，No.86，19-29.

12）中野敬之 (1997)：秋整枝が茶芽の生育に 及ぼすメカニズム。新しい農業技術 302 . 静岡県農政部.

13）静岡県茶業試験場 (1985)：13. 品種に適 した栽培法。創立80周年記念 静岡県茶 業試験場成績収録。静岡県茶業試験場, 静岡, pp. 40-41.

14）松尾喜義・池田奈実子(1998)：茶樹品種 における比葉重の変動特性について. 日 作東海支部報 125, pp. 21-23.

15）松尾喜義(1998）：‘やぶきた’一番茶新芽 における葉色と比葉重の年次間変動につ いて. 日作東海支部報 126, pp. 5-8. 